\title{
Erratum to: MHC class I genes of birds of prey: isolation, polymorphism and diversifying selection
}

Miguel Alcaide $\cdot$ Scott V. Edwards •

Luis Cadahía $\cdot$ Juan J. Negro

Published online: 23 October 2009

(C) Springer Science+Business Media B.V. 2009

\section{Erratum to: Conserv Genet}

DOI 10.1007/s10592-008-9653-7

Authors are willing to communicate a typo within the nucleotide sequence of primer MHCI-Int2F. This primer appears in the text as CATTTCCCTYGTGTTTCAGG, but the correct sequence is CATTTCCCTGGTYGTGTTTCA GG. The three bases missing are indicated in bold. Authors sincerely apologise for this relevant mistake.

The online version of the original article can be found under doi: 10.1007/s10592-008-9653-7.

M. Alcaide $(\bowtie) \cdot$ L. Cadahía $\cdot$ J. J. Negro

Estación Biológica de Doñana (CSIC), Pabellón de Perú. Avda.

$M^{\mathrm{a}}$ Luisa s/n, 41013 Sevilla, Spain

e-mail: malcaide@ebd.csic.es

S. V. Edwards

Department of Organismic and Evolutionary Biology,

Harvard University, 26 Oxford St., Cambridge, MA 02138, USA 